\title{
Academic autopsies in Brazil - a national survey
}

\author{
Aloísıo Felipe-Silva ${ }^{1}$, Márcia Ishigal² ${ }^{2}$ Thaís Mauad ${ }^{3}$ \\ ${ }^{1}$ University of São Paulo, Hospital Universitário, Anatomic Pathology Service, São Paulo, SP, Brazil \\ ${ }^{2}$ Federal University of São Paulo, Department of Pathology, São Paulo, São Paulo, SP, Brazil \\ ${ }^{3}$ University of São Paulo, School of Medicine, Department of Pathology, São Paulo, São Paulo, SP, Brazi
}

\section{SUMmARY}

Objective: To investigate the number and rate of academic autopsies, general organization, educational and research in Brazilian academic services.

Methods: Standardized questionnaires were sent to Brazilian medical schools $(n=177)$ and active pathology residency programs $(n=53)$ from March to June 2009. Data were collected for years 2003 to 2008.

Results: Thirty-two academic services in 11 Brazilian states answered the survey. Twenty-one (65.6\%) perform less than a hundred autopsies for natural causes and less than fifty pediatric or fetal autopsies/year. Twenty-four (75\%) perform less than a hundred adult autopsies/year. Many institutions (46.9\%) reported a drop in the number of autopsies in a six-year period. The total autopsy count and autopsy rate in 2008 ranged 1-632 (median $=80)$, and 0-66\% (mean $=10.6 \%$, respectively. A steady decrease in the total count of autopsies in a pool of 19 institutions was observed ( $\mathrm{p}<0.01)$. Median autopsy rates have fallen from $19.3 \%$, in 2003, to $10.6 \%$, in 2008 ( $p=0.07$ ). Significant discrepancies at autopsies led to changes in institutional healthcare practice in $37.5 \%$ of the services. The low number of autopsies was a limiting factor in undergraduate education for $25 \%$ of respondents. A minimum number of autopsies is required to complete the pathology residency program in $34.6 \%$ of the services.

Conclusion: The total number and the rate of academic autopsies have decreased in Brazil between 2003 and 2008. The number of autopsies and the general organization of academic services must be enhanced to improve medical education, research, and the quality control of patient care.

Key words: autopsy, Brazil, health surveys, education.

\section{INTRODUCTION}

The value of autopsies as an instrument for quality control of patient care, research, medical education, identification of new diseases or new manifestations of known diseases, and evaluation of the effectiveness of therapy is notorious and well established in the literature. ${ }^{1,2}$ However, the nonforensic (or academic) autopsy has been broadly considered a "dying art" 3 or a "vanishing" medical procedure ${ }^{4}$ mostly because of the worldwide dramatic fall in autopsy rates during the last decades ${ }^{5}$. Financial, philosophical and administrative issues have also contributed to a diffuse perception of autopsies as obsolete and useless. ${ }^{6}$

In Brazil, autopsies are performed in three different and independent institutions. Forensic (or coroner) au- topsies are assigned to medico-legal institutes (coroner's service), which are under the administration of the departments of public safety of each federal state. Nonforensic autopsies of those dying of natural causes without medical assistance are assigned to the Death Verification Services (Serviço de Verificação de Óbitos, SVO, in portuguese), which are usually under responsibility of the local or state department of health. Finally, academic (or medical) autopsies are performed upon clinical request in those nonforensic autopsies of patients dying under medical care, usually in teaching hospitals.

The number of academic autopsies has been falling dramatically over the last years in Brazil. This fact has important consequences for training of pathologists, but 
there are no data on the whole number of academic autopsies performed across the country. ${ }^{7,8}$

Inspired by the survey on North American data published by Horowitz and Noritoku, ${ }^{9}$ we saw an opportunity to investigate and bring up data about the academic autopsy services in Brazil.

\section{Methods}

From March to June 2009, with the support of the Brazilian Society of Pathology, standardized questionnaires were sent to all officially registered Brazilian medical schools ( $\mathrm{n}=177$ ) and active pathology residency programs $(\mathrm{n}=53)$. The questionnaire was largely based on the report by Horowitz and Noritoku, ${ }^{9}$ adapted to Brazilian national standards, and divided into the following sections: identification and administration; autopsy numbers, rate and performance; autopsy in medical education (undergraduate and residency in pathology) and autopsy in research. The respondents were asked to add any additional or subjective comments.

Academic services were defined as those having any teaching (including residency in pathology), or research activity. Thus, the SVOs and medico-legal institutes were not included in the final analysis, though some have generously sent data as well as valuable comments and suggestions.

\section{ResULtS}

\section{Answers and general characterization}

A total of 32 academic services distributed in 11 federal states (which represents about $70 \%$ of the national population), answered the questionnaire. Since some answers could be given completely or partially, the totals do not necessarily always add up to 32 . Table 1 summarizes the geographical and institutional data. This sample largely represents Brazilian educational or research academic institutions that perform autopsies. They are typically in hospital pathology services, with over 20 years of operation, linked to public universities, and predominantly located in capital cities and metropolitan areas in the South-central geo-economic region. In fact, only 4 of the 32 hospitals (12.5\%) were not linked to a medical school or university. This is a small group of reference public hospitals with research and/or residency programs. Additionally, 4 of the 32 institutions (12.5\%) also worked as local SVOs.

Sixteen (50\%) autopsy services said to be functioning seven days a week, during daytime $34.4 \%$ are closed on weekends). Twenty-six (81.3\%) have four or more pathologists and 19 (59.4\%) have up to 3 autopsy technicians. All respondents have in house histological processing and $23(71.9 \%)$ have photographic documentation.
TABLE 1 Geographical and institutional characteristics of 32 academic autopsy services

\begin{tabular}{|c|c|c|}
\hline & $\mathrm{N}$ & $(\%)$ \\
\hline \multicolumn{3}{|l|}{ Geographic region } \\
\hline Southeast & 24 & $(75)$ \\
\hline South & 04 & $(12.5)$ \\
\hline Central-west & 02 & $(6.2)$ \\
\hline North & 01 & $(3.1)$ \\
\hline Northeast & 01 & $(3.1)$ \\
\hline \multicolumn{3}{|l|}{ Federal states } \\
\hline São Paulo & 15 & $(46.9)$ \\
\hline Rio de Janeiro & 05 & $(15.6)$ \\
\hline Minas Gerais & 03 & $(9.4)$ \\
\hline Paraná & 02 & $(6.2)$ \\
\hline Espírito Santo & 01 & $(3.1)$ \\
\hline Rio Grande do Sul & 01 & $(3.1)$ \\
\hline Santa Catarina & 01 & $(3.1)$ \\
\hline Amazonas & 01 & $(3.1)$ \\
\hline Bahia & 01 & $(3.1)$ \\
\hline Distrito Federal & 01 & $(3.1)$ \\
\hline Goiás & 01 & $(3.1)$ \\
\hline \multicolumn{3}{|l|}{ Type of institutional funding } \\
\hline Federal government & 14 & $(43.8)$ \\
\hline State government & 08 & $(25)$ \\
\hline Private university or foundation & 06 & $(18.7)$ \\
\hline Mixed income & 04 & $(12.5)$ \\
\hline \multicolumn{3}{|l|}{ Time of existence } \\
\hline Up to 10 years & 03 & $(9.4)$ \\
\hline 10 to 20 years & 05 & $(15.6)$ \\
\hline More than 20 years & 23 & $(71.9)$ \\
\hline Did not answer & 01 & $(3.1)$ \\
\hline
\end{tabular}

\section{Autopsy volume, rate and performance}

Twenty-one (65.6\%) services perform less than a hundred autopsies for natural causes per year and less than fifty pediatric or fetal autopsies per year. Twenty-four $(75 \%)$ hold less than a hundred adult autopsies per year. Many institutions (46.9\%) reported a drop in the number of autopsies in the last five years. The total number of autopsies and autopsy rate in the year 2008 ranged $1-632($ median $=80)$ and $0-66 \%($ mean $=10.6 \%)$, respectively.

A steady and practically linear decrease in the total count of autopsies between years 2003 - 2008 based on 19 institutions with complete serial data was observed (Spearman's rank correlation -1.0 $\mathrm{p}<0.01$ ) (figure 1). 


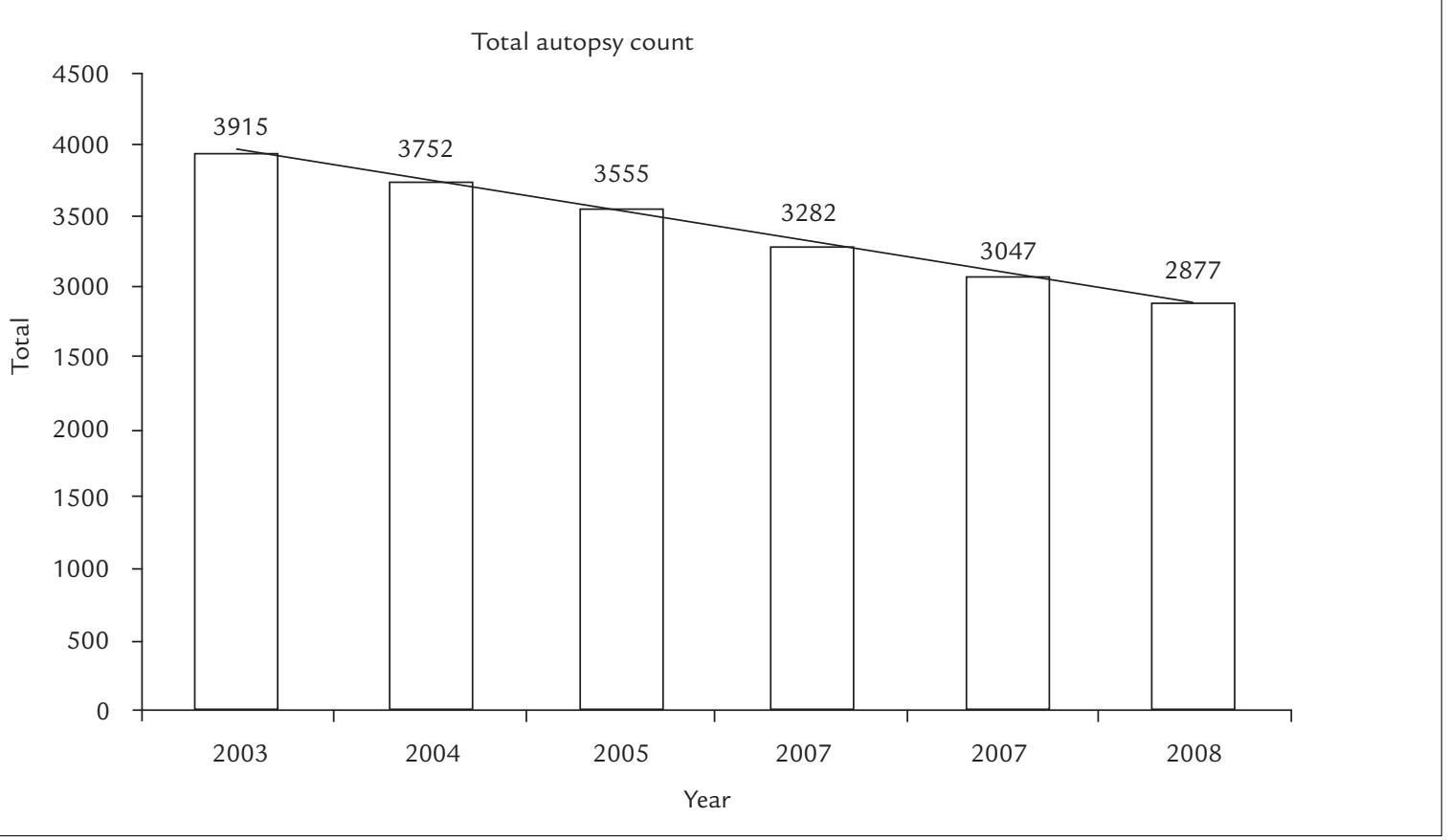

FIGURE 1 Total autopsy count between 2003 and 2008 (based on 19 institutions with complete serial data).

Data for autopsy rates in a 6-year period were available for 13 services. Mean autopsy rates have fallen from $23.3 \%$, in 2003 , to $18.4 \%$, in 2008 (Spearman's rank correlation $-0.48 \mathrm{p}=0.12$ ), while median rates dropped from $19.3 \%$ to $10.6 \%$ (Spearman's rank correlation $-0.60 \mathrm{p}=0.07$ ) (figure 2).

A preliminary report based on autopsy gross findings is issued within 48 hours in $53.1 \%$ of the services. The final report after histological analysis is issued within 30 days in $37.4 \%$. However, for most of the services there is no periodic disclosure of important indicators of the quality of the service and of the hospital care: number and rate of autopsies and time of issuing reports (84.4\%); annual reports of the autopsy findings (78.1\%); categorization of discrepancy rates (81.3\%); active communication of the autopsy findings to the clinical staff (68.8\%); incorporation of data to institutional programs of quality improvement (75\%); analysis of the causes of discrepancy $(68.8 \%)$ and peer review of autopsies as quality control (68.8\%).

In spite of these data, $37.5 \%$ of the services reported that significant discrepancies observed at autopsies were communicated between departments and led to changes in some kind of institutional healthcare practice. Importantly, $43.8 \%$ of the services answered that they had no information about potential changes in healthcare practices based on autopsy findings. Only $12.5 \%$ denied changes in healthcare practices based on autopsies.

\section{Undergraduate medical education}

With regard to undergraduate teaching, $84.4 \%$ of the services reported that medical students have the opportunity to watch autopsies, and this activity is related to a discipline of pathology in $40.8 \%$ of the answers. This activity is optional in most cases (62.5\%) and attended by less than $10 \%$ of students (according to $86.7 \%$ of those who responded to this item). Students usually attend to autopsies individually (40.6\%) or in small groups (31.2\%). The low number of autopsies was mentioned as a limiting factor by $25 \%$ of respondents. As expected, the opportunity to attend autopsies is higher in the school years when Pathology disciplines are taught $\left(1^{\text {st }}-6.3 \% ; 2^{\text {nd }}-\right.$ $37.5 \% ; 3^{\text {rd }}-50 \% ; 4^{\text {th }} 31.3 \% ; 5^{\text {th }}-18.8 \%$ and $\left.6^{\text {th }}-18.8 \%\right)$.

In general, much importance was given to the exposure of undergraduate students to autopsies with regard to the teaching of medicine $(78.1 \%)$, pathology $(81.3 \%)$, and to the education of future physicians on the request of autopsies and correct approach to the relatives of the deceased (78.1\%). To a lesser degree, this exposure was considered also quite important to the education of medical students as for professional (56.3\%) and personal issues $(59.3 \%)$ related to the end of life. 


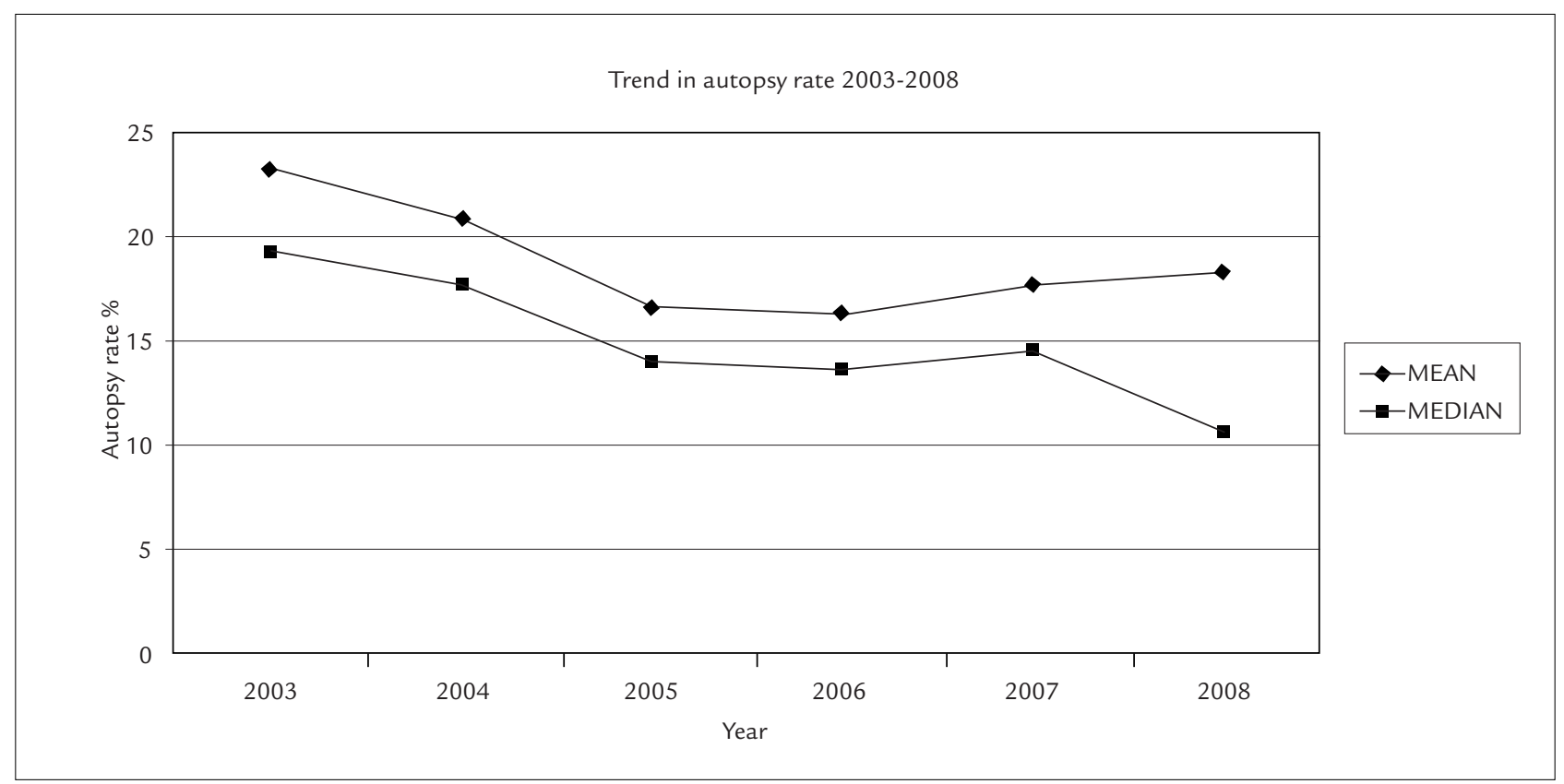

FIGURE 2 Trend in autopsy rate in a 6-year period, based on 13 academic autopsy services with complete serial data.

Residency and interaction with other departments

A total of 26 services ( $81.3 \%$ of the respondents) had an active residency training program in pathology. This sample corresponded to $49 \%$ of the officially registered pathology residency programs and to about $63.4 \%$ of the national available resident positions in pathology (National Commission for Medical Residency, personal communication). The number of residents per service was highly variable, with up to 3 residents in $23.1 \%$ and 9 or more residents in $30.8 \%$. Some services (34.6\%) require that the resident perform a minimum number of autopsies to complete the program (usually 50).

A staff of pathologists exclusively dedicated to autopsies is available in $26.9 \%$ of the services. The supervision of residents can be considered satisfactory. They are evaluated in their ability to perform autopsies (84.6\%); the autopsy findings and reports are reviewed by a staff pathologist (100\%); the reports are written with clinicopathological correlation (88.5\%); they present at least some cases in intradepartmental meetings (92.3\%) and interdepartmental sessions (92.3\%); photographic documentation $(100 \%)$ and ancillary methods $(100 \%)$ are available in virtually all pathology residency programs.

The main interaction with other departments occurs through regular participation in meetings or committees of complications and deaths (50\%). For most services there is no participation from residents $(87.5 \%)$ or staff $(62.5 \%)$ from other departments in autopsies. Only $43.7 \%$ promote regular meetings with other departments.

\section{Autopsy in research}

There was no published article primarily related to autopsies in the last 5 years in $31.2 \%$ of the services and no article in collaboration with other clinical departments in $18.7 \%$. For $75 \%$ of the academic services there was at least one ongoing research project by the time of this survey.

\section{Discussion}

Academic autopsy rates have been dropping worldwide during the last decades. ${ }^{10-12}$ Few published reports have confirmed this trend in Brazilian services. ${ }^{6-8}$ To the best of our knowledge, this is the first nationwide investigation on academic autopsy number, rates and medical educational potential in Brazil.

This sample largely represents major academic autopsy services in Brazil, since leading universities in most densely populated federal states answered the questionnaire. However, the exact proportion of national academic autopsy services could not be determined. At the time this survey started, there were 177 medical schools and 53 registered residency programs in Brazil, but only an unknown fraction of these institutions keeps autopsy services. Additionally, in many cities, autopsies are performed by medico-legal institutes and SVOs, which were not included in this survey.

In the Horowitz and Noritoku ${ }^{9}$ survey, $31 \%$ of American institutions performed less than a hundred autopsies per year. We found a higher proportion of low volume ( $\leq 100$ cases) services in Brazilian academic autopsy 
services. On the other hand, we found two large institutions with more than 500 cases per year. Comparing to their data, low volume services predominate in Brazil, while medium volume services $(101-250$ cases $)$ predominate in USA.

This survey confirms a significant drop in the total number of academic autopsies and a decreasing trend in the medical autopsy rates in Brazil in recent years. This finding follows the same pattern reported in many other countries. ${ }^{4-6,13}$ Even in this short 6-year period (2003 2008) the decline is consistent. The present series starts in 2003 with a median autopsy rate of $19.3 \%$, but some Brazilian institutions used to have medical autopsy rates approaching $80 \%$ in the early 1990 's. ${ }^{1,6,14}$ The reasons for this decline have been extensively discussed in the literature, ${ }^{4}$ and many of those explanations apply to Brazil. The withdrawal of the written consent for autopsy upon hospital admission has been blamed for a dramatic fall in autopsy count in one traditional Brazilian institution. ${ }^{8}$

A unique characteristic of autopsy services in Brazil may contribute to this observed drop as well. In many locations, hospital deaths in patients dying without an ascertained diagnosis may be referred to the SVOs. Consequently, these hospitals may never develop an in-house autopsy service. For instance, in Vitória, state of Espírito Santo, autopsies referred from hospitals make up to $42 \%$ of the local SVO cases. ${ }^{15}$

Most of the academic autopsies services in Brazil are located in South-Central geo-economic region. One possible explanation for this finding is that the speed of population growth in most of Central-West and Northern regions increased after the foundation of the country's capital Brasília in 1960. Many medical schools have been opened in the last three decades, without a tradition in autopsy performance. Therefore non-forensic autopsies in those regions are now being performed preferentially in SVOs, instead of academic services. In fact, Federal Regulation has established a National Death Verification Network in 2005 in order to reduce the high number of unspecified and ill-defined causes of death especially in the North and Northeast regions. ${ }^{16}$ Actually, while the proportion of SVO autopsies seems to be stable in São Paulo, ${ }^{17}$ there seems to be a rising trend in SVO autopsies in the whole country $(5.52 \%$ in 2006 to $6.16 \%$ in 2010 , unpublished data).

We have detected high rates of undisclosed indicators of quality of the service and of the hospital care. As described elsewhere, ${ }^{18}$ pathologists and pathology services have their share of responsibility on declining autopsy rates. This is most likely due to local cultural, admin- istrative and legal reasons, since there seems to be no specific official regulation or quality assurance program in autopsy pathology besides general medical, civilian and sanitary regulations.

Despite the general high rate of undisclosed indicators, $37.5 \%$ of the services reported that major discrepancies between autopsies and clinical findings were communicated to institutional board and led to review of heath diagnostic and therapeutic procedures. This is quite important if one notes that another $43.8 \%$ were not able to answer this particular question. It means that there is much room for improvement in Brazilian healthcare system based on the analysis of autopsy findings. In regions where modern medical technology is not yet fully available, academic autopsies might be even more important in accessing medical discrepancies and contributing to the quality of care.

It may be noted that increasing the exposure of medical students to autopsy conferences with clinical correlation, especially in last years of medical school, may be more useful in showing the importance of the autopsy and of the pathologist, as well as in the training the future physicians in filling out the death certificate, clarifying of the relatives and in the correct indication of an autopsy.

In summary, we confirmed a decline in the number and rate of academic autopsies in Brazil in the last years. The causes for this decline are similar to worldwide data, and jeopardize pathology residency training, undergraduate teaching and hospital quality assurance. In addition, the implementation of a national network of SVOs seems to be peculiar to this country, and may be competing with academic services. Pathology departments should search for closer interaction with the SVOs in an attempt to reverse this worrying scenario for academic autopsies in Brazil.

\section{ACKNOWLEDGemEnTS}

The authors thank all the pathologists and services who completed the surveys and who kindly shared comments and suggestions. We are also thankful to the Brazilian Society of Pathology (Sociedade Brasileira de Patologia) for the support in contacting many institutions and pathologists nationwide.

Dr. Mauad is funded by the CNPq.

\section{Resumo}

Autópsias acadêmicas no Brasil - um inquérito nacional

Objetivo: Investigar o número e a taxa de autópsias acadêmicas, organização geral, ensino e pesquisa em serviços acadêmicos brasileiros. 
Métodos: Questionários padronizados enviados para escolas médicas brasileiras $(\mathrm{n}=177)$ e programas de residência em patologia ativos $(n=53)$ de março a junho de 2009. Dados coletados referentes ao período de 2003 a 2008 .

Resultados: Trinta e dois serviços em 11 estados responderam à pesquisa. Vinte e um $(65,6 \%)$ realizam menos de cem autópsias de causas naturais e menos de cinquenta autópsias fetais ou pediátricas/ano. Vinte e quatro (75\%) realizam menos de cem autópsias de adultos/ano. Muitas instituições $(46,9 \%)$ relataram queda no número de autópsias em seis anos. A contagem total e a taxa de autópsias em 2008 variaram, respectivamente, de 1 a 632 (mediana $=80$ ) e de 0 a $66 \%$ (média $=10,6 \%$ ). Foi observada uma redução contínua no total de autópsias em um grupo de 19 instituições $(\mathrm{p}<0,01)$. A mediana da taxa de autópsias caiu de 19,3\%, em 2003, para 10,6\%, em 2008 $(\mathrm{p}=0,07)$. Discrepâncias significativas observadas em autópsias levaram a mudanças na prática institucional de saúde em $37,5 \%$ dos serviços. O baixo número de autópsias foi limitante no ensino de graduação para $25 \%$ dos entrevistados. Um número mínimo de autópsias é necessário para completar o programa de residência em patologia em 34,6\% dos serviços.

Conclusão: $\mathrm{O}$ número total e a taxa de autópsias acadêmicas diminuíram no Brasil entre 2003 e 2008. O número de autópsias e organização geral dos serviços acadêmicos deve ser melhorado para fortalecer a educação médica, pesquisa e controle de qualidade prestado ao paciente.

Unitermos: autópsia, Brasil, inquéritos epidemiológicos, educação.

\section{References}

1. Kotovicz F, Mauad T, Saldiva PH. Clinico-pathological discrepancies in a general university hospital in São Paulo, Brazil. Clinics (São Paulo). 2008;63(5):581-8.

2. Roulson J, Benbow EW, Hasleton PS. Discrepancies between clinical and autopsy diagnosis and the value of post mortem histology; a meta-analysis and review. Histopathology. 2005;47(6):551-9.

3. Levison DA. Autopsy teaching: a dying art? Med Teach. 2004;26(4):293-4.

4. Shojania KG, Burton EC. The vanishing nonforensic autopsy. N Engl J Med. 2008;358(9):873-5.

5. Xiao J, Krueger GR, Buja LM, Covinsky M. The impact of declining clinical autopsy: need for revised healthcare policy. Am J Med Sci. 2009;337(1):41-6.

6. Pompilio CE, Vieira JE. The technological invention of disease and the decline of autopsies. São Paulo Med J. 2008;126(2):71-2.

7. Moreira DR, Lana AMA, Godoy P. Estudo sobre a contribuição da autópsia como método diagnóstico. J Bras Patol Med Lab. 2009;45(3):239-45.

8. Rodrigues FR, Lopes VGS, Lopez CL, Filho PJS, Silva RCL, Silva LE, et al. O decréscimo vertiginoso das autópsias em um hospital universitário do Brasil nos últimos 20 anos. J Bras Patol Med Lab. 2011;47(4):445-50.

9. Horowitz RE, Naritoku WY. The autopsy as a performance measure and teaching tool. Hum Pathol. 2007;38(5):688-95.

10. Wood MJ, Guha AK. Declining clinical autopsy rates versus increasing medicolegal autopsy rates in Halifax, Nova Scotia. Arch Pathol Lab Med. 2001;125(7):924-30.

11. Zhu MH, Yu DH. Fluctuations in the rate of autopsy in China. Chin Med J (Engl). 2011;124(20):3403-7.

12. Geiler G. [The year 1989. A turning point for pathology at the University of Leipzig?]. Pathologe. 2001;22(4):235-40.

13. Chariot P, Witt K, Pautot V, Porcher R, Thomas G, Zafrani ES, et al. Declining autopsy rate in a French hospital: physician's attitudes to the autopsy and use of autopsy material in research publications. Arch Pathol Lab Med. 2000;124(5):739-45.

14. Milani Junior R, Montebello SC, Pizzotti NJE, Franco Junior A, Campos FPF. Value of the autopsy in detecting diagnostic errors. Rev Bras Ter Intensiva. 1991;3(Supl 1):250.

15. Serviço de Verificação de Óbitos Gerência de Vigilância em Saúde - GEVS Secretaria da Saúde, Governo do Espírito Santo. 2012 [citado 8 jul 2013]. Disponível em: http://www.saude.es.gov.br/download/Estatistica_ Obitos_2011_2012.pdf

16. Brazil. Ministry of Health. Portaria 1.405, 2006 Jun 29 [cited 2013 jul 8] Available from: http://dtr2001.saude.gov.br/sas/PORTARIAS/Port2006/ GM/GM-1405.htm

17. Rozman MA, Eluf-Neto J. Necropsia e mortalidade por causa mal definida no Estado de São Paulo. Rev Panam Salud Publica. 2006;20(5):307-13.

18. Royal College of Pathologists of Australasia Autopsy Working Party. The decline of the hospital autopsy: a safety and quality issue for healthcare in Australia. Med J Aust. 2004;180(6):281-5 